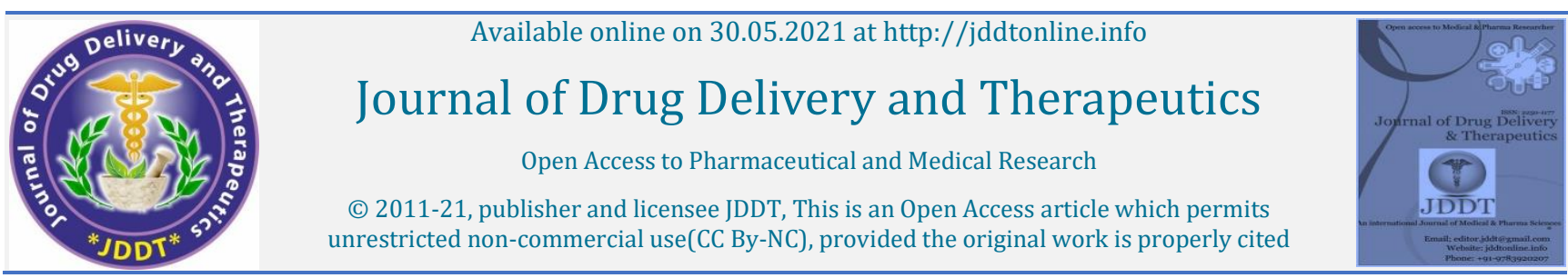

\title{
Relationship of Feeding Patterns and History of TB and Diarrhea in Children 2-5 Years Old and Stunting in Sukahayu Village, Sumedang, West Java, April 2019
}

\author{
Ance Adriani* \\ Faculty of Medicine, Universitas Kristen Indonesia, Jakarta, Indonesia
}

\begin{tabular}{ll}
\hline Article Info & \\
\hline & Article History: \\
& Received 23 March 2021 \\
& Accepted 21 May 2021 \\
& Published 30 May 2021 \\
\hline
\end{tabular}

Cite this article as:

Adriani A, Relationship of Feeding Patterns and History of TB and Diarrhea in Children 2-5 Years Old and Stunting in Sukahayu Village, Sumedang, West Java, April 2019, Journal of Drug Delivery and Therapeutics. 2021; 11(3):170-176

DOI: http://dx.doi.org/10.22270/jddt.v11i3.4814

*Address for Correspondence:

Ance Adriani, Faculty of Medicine, Universitas Kristen Indonesia, Jakarta, Indonesia

\begin{abstract}
Stunting is when children under five years old (toddlers) have a height-for-age index below minus two standard deviations based on the WHO standard. Stunting was a chronic nutritional problem caused by socioeconomic, maternal nutrition during pregnancy, nutritional intake during infancy, and infectious diseases. The purpose of this study was to determine the relations between feeding patterns and a history of Tuberculosis or diarrhoea in children aged 2-5 years with stunting. The type of this research was observational with a cross-sectional design. Samples were taken using a total sampling method of 34 samples. The study was conducted in April 2019 in Sukahayu Village, West Java. Data were collected by interviewing, measuring height and filling out the questionnaire. Bivariate analysis used Spearman's rho test. The results showed that stunting toddlers age the most at 25-36 month (50\%), gender was equal between boy and girl (50\%), 82.4\% of stunting toddlers had a good pattern of feeding, had a history of TB $14.7 \%$ and had a history of diarrhoea $76.5 \%$. The results of the Spearman's rho test showed no correlations between feeding patterns $(\mathrm{p}=0.22)$, history of TB $(\mathrm{p}=0.55)$ and history of diarrhoea $(\mathrm{p}=0.37)$ with stunting in Sukahayu Village. This study advises governments and health agencies to improvethe nutritional status of stunting children and in the provision of standard anthropometric devices. The community is expected to get quality education and provide balanced nutrition to improve the health of children.
\end{abstract}

Keywords: Stunting, feeding pattern, history of Tuberculosis, history of diarrhoea

\section{INTRODUCTION}

Stunting (dwarfism) is a condition in which children under five years of age (toddlers) have a length or height that is less when compared to their age. This condition is measured by a length or height that is more than minus two standard deviations from the World Health Organization (WHO) median child growth standard. The incidence of short toddlers or commonly referred to as stunting, is one of the nutritional problems experienced by toddlers in the world today. In 2017, $22.2 \%$ or around 150.8 million children under five in the world were stunted. The data on the prevalence of stunting under five collected by WHO, Indonesia is the third country with the highest prevalence in the Southeast Asia/South-East Asia Regional (SEAR) region. ${ }^{1}$ Where toddlers were very short and short aged 0-59 months in 2017 are $9.8 \%$ and $19.8 \%$. Toddler stunting is a chronic nutritional problem caused by many factors such as socioeconomic conditions, maternal nutrition during pregnancy, illness in infants, and lack of nutritional intake in infants. Toddlers with stunting in the future will have difficulty achieving optimal physical and cognitive development. ${ }^{1}$ The toddler period is a period that is very sensitive to the environment, so that more attention is needed, especially nutritional adequacy. ${ }^{2}$ Nutritional problems, especially stunting in toddlers, can hinder the development of children, with negative impacts that will last in the next life, such as intellectual decline, susceptibility to non-communicable diseases, decreased productivity, causing poverty and the risk of giving birth to babies with low birth weight. ${ }^{3}$

One of the causes of nutritional problems in toddlers is the poor feeding pattern given to toddlers, which will affect toddlers' growth process because the nutritional intake given is essential for toddlers' growth, health, and intelligence. ${ }^{4}$ It can cause children under five to experience an increased risk of morbidity and mortality, so that a healthy eating pattern will positively impact health in the future. ${ }^{5}$ One of the causes of morbidity in infants is an infectious disease caused by diarrhoea because poor hygiene and sanitation can interfere with the absorption of nutrients in the digestive process. ${ }^{1}$ Some infectious diseases such as Tuberculosis (TB) can also cause under-fives to lose weight. The proportion of pulmonary TB cases in Indonesia in 2015 in the age group 0-14 years reached $8.59 \%$ and an increase compared to 2014, namely $7.10 \%$ and in 2013, namely $7.92 \% .^{6}$ Tuberculosis in children under five has the potential to cause various problems, ranging from cases of failure to thrive, disability, and even death, depending on the organ being attacked and the severity of the case. If this condition occurs for a long time and is not accompanied by adequate 
intake for the healing process, it can result in stunting. ${ }^{6}$

In connection with this description, researchers are interested in researching the relationship between feeding patterns and a history of TB or diarrhoea for children aged 25 years to the incidence of stunting in the village of Sukahayu, Sumedang, West Java. It is undoubtedly useful, in addition to knowing toddlers who have a history of diarrhoea or TB. It can also be information for mothers that the importance of adequate nutrition for toddlers through good feeding patterns is one way to prevent toddlers from experiencing stunting. The formulation of the problem that is answered in this study is "How is the relationship between feeding patterns and a history of TB or diarrhoea to the stunting incidence in the village of Sukahayu, Sumedang, West Java. This research was conducted to determine the pattern of feeding and a history of TB or diarrhoea in the incidence of stunting in the village of Sukahayu, Sumedang, West Java.

\section{LITERATURE REVIEW}

Stunting was defined as a height or body length two points below the standard deviation (SD) according to age and sex. The state of stunting is determined based on nutritional status using the index of body length per age $(\mathrm{PB} / \mathrm{U})$ or height per age $(\mathrm{TB} / \mathrm{U})$, wherein anthropometric standards for assessing children's nutritional status and the measurement results are at the threshold (Z-Score) <- 2 SD to $-3 \mathrm{SD}$ (short/stunted) and <-3 SD (very short / severely stunted). Stunting is a chronic malnutrition problem caused by insufficient nutritional intake for a long time due to feeding that is not following nutritional needs. Stunting can occur when the fetus is still in the womb and does not appear until the child is two years old 7,8 . Stunting can be seen when a toddler has been weighed and measured the length or height, then compared with the standard, and the results are below average. So physically, toddlers will be shorter than toddlers their age. This calculation uses the standard Z score from WHO. Normal, Short and Very Short are nutritional status which is based on the index of Body Length according to Age $(\mathrm{PB} / \mathrm{U})$ or Height for Age $(\mathrm{TB} / \mathrm{U})$ which is the equivalent of the terms stunted (short) and severely stunted (very short). The following is the classification of stunting nutritional status based on indicators of height per age (height/age).7,8,9

Very short: Z score $<-3.0$

Short $\quad:$ Z score $<-2.0$ until Z score $\geq-3.0$

Normal : Zscore $\geq-2.0$

Below is a classification of stunting nutritional status based on indicators of height/age and body weight/height (weight/height). ${ }^{7}$

Short-skinny : Z-score $\mathrm{BH} / \mathrm{age} \quad<-2,0$ and Z-score
BW/BH $<-2,0$
Short - normal : Z-score $\mathrm{BH} /$ age $<-2.0$ and Z-score
BW/BH between -2.0 to 2.0

Stubborn: Z-score $\geq-2.0$ to Z-score $\leq 2.0$

Nutritional Status Monitoring (PSG) 2017 shows the prevalence of stunting under five in Indonesia is still high, namely $29.6 \%$ above the limit set by WHO (20\%). Compared with countries in Latin America, the Middle East and North Africa, and Sub-Saharan Africa, Indonesia is still higher. Ricardo research in Bhutta in 2013 states that stunting under five contributes to 1.5 million (15\%) of under-five mortality in the world and causes 55 million children to lose their healthy life every year. ${ }^{10}$ Several risk factors can influence the occurrence of stunting, namely: gender, parental education, ${ }^{11}$ parental economy, ${ }^{12}$ clean and healthy lifestyle, ${ }^{13}$ nutritional intake of children under five, infectious diseases, food availability. ${ }^{11}$

Adverse effects that can be caused by stunting15: a) Short term is disruption of brain development, intelligence, physical growth disorders, and metabolic disorders in the body; and b) In the long term, the dire consequences that can be caused are reduced cognitive abilities and learning achievement, decreased immunity so that they get sick quickly, and a high risk of diabetes, obesity, heart and blood vessel disease, cancer, stroke, and disability in old age. All of this will reduce the quality of Indonesia's human resources, productivity and national competitiveness. Diet is the most important behaviour that can affect the state of nutrition. The quantity and quality of food and beverages consumed will affect the health level of individuals and society. Dietary recommendations in recent decades have taken into account the proportion of each food group according to their supposed needs. For example, it is currently recommended to consume more vegetables and fruits than previously recommended. During the first six months, babies only need breast milk because breast milk provides all the food and fluids that the baby needs for the first six months, and even in hot weather, breast milk will be able to quench the baby's thirst. Do not give anything other than breast milk, even plain water, to the baby during the first six months as this will make the baby lazy to breastfeed and reduce the amount of milk production. Water or other fluids and food can make babies sick because they can damage their digestion. ${ }^{16}$

Here are some of the benefits of breast milk: (1) Breast milk provides all the food and drinks with a baby needs for the first six months. (2) Providing exclusive breastfeeding for the first six months will protect the baby from various diseases, such as diarrhoea and respiratory infections. (3) If the mother gives exclusive breastfeeding to the baby during the first six months and has never experienced menstruation, eating the mother will avoid pregnancy. ${ }^{17}$ Complementary foods of breast milk (MP-ASI) is given when the baby is six months to 24 months old. MPASI is helpful for meeting nutritional needs apart from breast milk. MP-ASI in the solid or liquid food form, which is given gradually according to the age and digestive ability of the baby or child. The recommended dietary patterns for infants and toddlers and the frequency and amount of complementary feeding can be seen from the table below. ${ }^{18}$ 
Table 1: Recommended Diet for Infants and Toddlers

\begin{tabular}{|c|c|c|c|c|}
\hline \multicolumn{2}{|c|}{ Age (month) } & Mashed Food & Soft food & Family Meals \\
\hline \multicolumn{2}{|c|}{$0-6$} & & & \\
\hline & \multicolumn{3}{|c|}{$6-9$} \\
\hline \multicolumn{5}{|c|}{$9-12$} \\
\hline \multicolumn{5}{|c|}{$12-24$} \\
\hline \multicolumn{5}{|l|}{ Description: } \\
\hline \multicolumn{5}{|c|}{ Age 0 - 6 months: breastfeeding only } \\
\hline \multicolumn{5}{|c|}{ Age 6 - 9 months: given breast milk and alternating crushed foods } \\
\hline \multicolumn{5}{|c|}{ Age 9-12 months: given alternating breastmilk and soft food } \\
\hline \multicolumn{5}{|c|}{ Age 12-24 months: given breast milk and family food } \\
\hline \multicolumn{5}{|c|}{ Table 2: Frequency and Amount of $c$ Given } \\
\hline Age & Frequency & & The & with each meal \\
\hline $6-9$ months & $2-3 \times$ mashed foo & $1-2 \mathrm{x}$ snack + breast milk & $\begin{array}{l}2-3 \\
\text { incl }\end{array}$ & $\begin{array}{l}\text { ns full at each meal and slowly } \\
\text { lf } 1 / 2 \text { of the } 250 \mathrm{ml} \text { cup per meal }\end{array}$ \\
\hline $9-12$ months & $3-4 \mathrm{x}$ soft food +1 & x snack + breast milk & $1 / 2 \mathrm{C}$ & \\
\hline 12 - 24 months & 3-4 x family food & $-2 \mathrm{x}$ snack + breast milk & $3 / 42$ & \\
\hline
\end{tabular}

The suggested number of servings according to energy sufficiency for 1-3 years and 4-6 years age groups: ${ }^{19}$

Table 3: Amount of Portion for 1-3 Years and 4-6 Years Age Groups

\begin{tabular}{lll}
\hline Food material & Children aged 1-3 years 1125 kcal & Children 4-6 years old 1600 kcal \\
\hline Rice & $3 \mathrm{p}$ & $4 \mathrm{p}$ \\
Vegetables & $1.5 \mathrm{p}$ & $2 \mathrm{p}$ \\
Fruit & $3 \mathrm{p}$ & $3 \mathrm{p}$ \\
Tempe & $1 \mathrm{p}$ & $2 \mathrm{p}$ \\
Meat & $1 \mathrm{p}$ & $2 \mathrm{p}$ \\
Breast milk & Continued until the age of 2 years & \\
Milk & $1 \mathrm{p}$ & $1 \mathrm{p}$ \\
Oil & $3 \mathrm{p}$ & $4 \mathrm{p}$ \\
Sugar & $2 \mathrm{p}$ & $2 \mathrm{p}$ \\
\hline
\end{tabular}

Tuberculosis (TB) is a common and often deadly infectious disease caused by mycobacterium, usually Mycobacterium tuberculosis in humans. TB usually attacks the lungs but can also affect other parts of the body. TB can be spread through the air when a person who has this disease coughs, sneezes, or spits up. Most human infections result in infection, are asymptomatic latent, and about one in ten latent infections eventually progress to active disease, which, if left untreated, kills more than half of victims. ${ }^{20}$

The management of TB in children is an inseparable unity between medical administration, nutritional management, and the surrounding environment. Medical provision is inseparable from health education to the public or the patient's parents about the importance of taking the medication regularly for a long time and monitoring the schedule for administering drugs, knowing that the drug is being taken, and so on. Since the late 1990s, several diseases have recurred and become a problem, especially in developed countries TB. WHO estimates that one-third of the world's population ( 2 billion people) has been infected with M. tuberculosis, with the highest rates in Africa, Asia and Latin America. Tuberculosis is still the leading cause of death in developing countries. The data show that this disease is most concentrated in metropolitan urban centres. Here a meaningful percentage of the population living in poor neighbourhoods facilitate the transmission of the disease. Reports of TB in children are rare. It is estimated that the number of TB cases in children per year is $5 \%$ to $6 \%$ of the total TB cases. In developing countries, Tuberculosis in children aged $<15$ years is $15 \%$ of all TB cases, while in developed countries, the rate is lower at $5-7 \%{ }^{21}$

The risk factors for TB infection include children who have contact with adults with active TB, endemic areas, use of intravenous drugs, poverty, and an unhealthy 
environment. The most critical risk factor for TB infection in children is exposure to adults infectious. It means, babies of a mother with a positive sputum smear have a high risk of TB infection. The closer the baby is to the mother, the more likely it is to be exposed to infectious droplet nuclei. The risk of transmitting germs from adults to children is higher if the adult patient has a positive sputum smear, there is a large infiltrate in the upper lobe or cavity, large and watery sputum production, productive and robust cough, and lack of environmental factors. Healthy, especially the air circulation, is not good.

People who have been infected with TB germs will not always be sick with TB. The following are the factors that can cause the progression of TB infection to become sick with TB. The first risk factor is age. Children $\leq$ five years of age have a greater risk for progression of infection to become sick with $\mathrm{TB}$, perhaps because their cellular immunity is not yet fully developed. The risk of getting TB disease will decrease with age. Other risk factors are conversion of tuberculin tests in the past 1-2 years, malnutrition, immunocompromised states, malignancy, organ transplantation, immunosuppressive treatment, diabetes mellitus, chronic renal failure, and silicosis. No less essential factors in TB epidemiology are low economic status, low income, overcrowding, unemployment, and low education.

Diarrhoea is still a public health problem in developing countries, including Indonesia and is one of the highest causes of death and morbidity in children, especially under five years of age. As many as 6 million children die each year due to diarrhoea. Most of these occurrences occur in developing countries. $42 \%$ of infant deaths are caused by diarrhoea. For groups 1-4 years, death due to diarrhoea reaches $25.5 \% .22$ In general, the mode of transmission of diarrhoea is through the faecal-oral method, namely through food or drinks contaminated by enteropathogens or direct hand contact with sufferers or items that have been contaminated with patient faeces or indirectly through flies. In short, it can be said through "4F", namely finger (finger), flies (fly), fluid (fluid), and field (environment).

In general, diarrhoea is caused by two things, namely disruption in the absorption process. Diarrhoea due to absorption disorders, namely the volume of fluid in the colon, is greater than the absorption capacity. There is a disturbance in the small intestine. It results in a decrease in the absorption process or an increase in the secretion process. Diarrhoea can also occur due to motility, inflammatory and immunological disorders. ${ }^{23}$ Diarrhoea due to absorption disorders or osmotic diarrhoea can be caused by: a) Consumption of magnesium hydroxide, thereby reducing intestinal absorption function; b) sucraseisomaltase deficiency; c) The presence of material that is not absorbed causes the intraluminal material in the proximal small intestine to be hypertonic and cause hyperosmolarity. Due to the difference in osmotic pressure between the intestinal lumen and blood, water will flow towards the hehunum lumen in the permeable jejunal segment, and water will collect in the intestinal lumen. Na will follow into the lumen, thereby accumulating intraluminal fluid with normal Na levels. ${ }^{24}$ Diarrhoea due to general malabsorption usually caused by damage to cells (which generally absorb $\mathrm{Na}$ and water) can be caused by infection with viruses or germs, such as Salmonella, Shigella or Campylobacter. It can also be caused by idiopathic inflammatory bowel disease, toxins, or certain drugs. A characteristic feature of the disease-causing small bowel malabsorption is villi atrophy. ${ }^{25}$

Diarrhoea due to secretory disorders or secretory diarrhoea can occur due to hyperplasia of crypts, luminal secretagogues, and blood-borne secretagogues. Generally, cryptic hyperplasia will cause villi atrophy. In luminal secretagogues, lumen secretion is influenced by bacterial enterotoxins and stimulating chemicals such as laxans, dihydroxyl form bile salts, and long-chain fatty acids. In secretagogin blood-borne, diarrhoea is generally caused by E. Coli or Cholera enterotoxins. ${ }^{26}$ Diarrhoea due to peristalsis is caused by changes in intestinal motility which will affect absorption. Both increased or decreased motility can cause diarrhoea. Decreased motility can result in bacteria overgrowth, which in turn can cause diarrhoea. Diarrhoea due to hyperperistalsis in children is rare. Watery diarrhoea can be caused due to hypermotility in cases of colon irritability in infants. ${ }^{27}$

Diarrhoea due to inflammation can occur due to loss of epithelial cells and damage to tight junctions, causing water, electrolytes, mucus and protein to accumulate in the lumen. Usually, diarrhoea due to inflammation is associated with other types of diarrhoea such as osmotic diarrhoea and secretory diarrhoea. Pathogenic enteral bacteria will affect the structure and function of the tight junction, induce secretion of fluids and electrolytes, and activate the inflammatory cascade. The effect of bacterial infection on the tight junction will affect the anatomical arrangement and absorption function and changes in protein composition. Research by Berkes J et al. 2003 shows that the role of enteral pathogenic bacteria in diarrhoea is influenced by changes in the barrier tight junction by toxins or germ products, namely changes in the cellular cytoskeleton and specific tight junctions. The effect will cause hypersecretion of chlorides which will be followed by sodium and water. ${ }^{28}$ Immunologically associated diarrhoea is associated with hypersensitivity reactions of types I, III and IV. Type I reaction is a reaction between mast cells and $\operatorname{IgE}$ and food allergens. Type III reactions are, for example, in gastroenteropathy, whereas type IV reactions are found in celiac disease and protein loss enteropathies. Chemical mediators resulting from the immune response will cause the mucosal surface area to decrease due to tissue damage, stimulating chloride secretion followed by sodium and water.

\section{RESEARCH METHOD}

The type of research used in this research is an observational analytic study with a cross-sectional design to see the relationship between feeding patterns and a history of TB or diarrhoea with the incidence of stunting in Sukahayu Village, Sumedang, West Java, April 2019. April 5, 2019. Research site in Sukahayu Village, Sumedang, West Java. This study population were all toddlers aged 2-5 years who experienced stunting in Sukahayu, Sumedang, West Java in April 2019. From previous research, it was found that there were 34 children with stunting in Sukahayu village.

Furthermore, the sampling technique used is total sampling, where the sampling is the same as the existing population. The research instruments used were stationery, data recording sheets, questionnaire sheets, anthropometric tools. Data collection was carried out using questionnaires and anthropometric measurements. Data processing is done with a computerized system through editing, coding, and cleaning. Data analysis was performed using univariate and bivariate analysis procedures to explain or describe the description and relationship between the research variables. The presentation of the research data is then presented descriptively in the form of narration, text, tables and graphics. 


\section{RESULT AND DISCUSSION}

Table 4: Frequency Distribution of Nutritional Status Based on Height Index by the age of Stunting Toddlers

\begin{tabular}{lll}
\hline TB/Age Nutritional status & Frequency & \% \\
\hline Very short & 2 & 5,9 \\
Short & 32 & 94,1 \\
\hline Total & 34 & 100,0
\end{tabular}

Based on table 4, the nutritional status based on the height index according to the age of stunting of children under five in Sukahayu Village was found that two children were very short (5.9\%) and 32 children were short (94.1\%).

Table 5: Frequency Distribution of Stunting Toddler Age

\begin{tabular}{lll}
\hline Child Age & Frequency & \% \\
\hline $25-36$ months & 17 & 50,0 \\
$37-48$ months & 8 & 73,5 \\
$49-60$ months & 9 & 100,0
\end{tabular}

Based on table 5, the age frequency distribution for stunting children in Sukahayu Village is highest in the 25-36 months age group as many as 17 children (50.00\%). In the 37-48 month age group, there were eight children $(23.53 \%)$. In the 49-60 month age group, there were nine children $(26.47 \%)$.

Table 6: Frequency Distribution of Sex in Toddler Stunting

\begin{tabular}{lll}
\hline Gender & Frequency & $\mathbf{\%}$ \\
\hline Male & 17 & 50,0 \\
Female & 17 & 50,0 \\
\hline Total & 34 & 100,0
\end{tabular}

Based on table 6, the sex distribution of stunting children in Sukahayu village is the same, where the sexes of boys and girls are 17 children $(50.0 \%)$ respectively.
Table 7: Distribution of Stunting Toddler Feeding Patterns

\begin{tabular}{lll}
\hline Feeding Patterns & Frequency & $\mathbf{\%}$ \\
\hline Good & 28 & 82,4 \\
Not good & 6 & 17,6 \\
\hline Total & 34 & 100,0
\end{tabular}

Based on table 7 , the distribution of a good feeding pattern is 28 children (82.35\%), more than six children (17.65\%).

Table 8: Distribution of TB History of Stunting Toddlers

\begin{tabular}{lll}
\hline History of TB & Frequency & $\mathbf{\%}$ \\
\hline Ever & 5 & 14,7 \\
Never & 29 & 85,3 \\
\hline Total & 34 & 100,0 \\
\hline
\end{tabular}

Based on table 8, the distribution of TB history found that many children had never experienced TB, namely 29 children (85.3\%) and only five children who had experienced TB (14.7\%).

Table 9: Frequency Distribution of Stunting Toddler Diarrhea History

\begin{tabular}{lll}
\hline History of Diarrhea & Frequency & \% \\
\hline Yes & 26 & 76,5 \\
Not & 8 & 23,5 \\
\hline Total & 34 & 100,0
\end{tabular}

Based on table 9, the distribution the diarrhoea history in children, many children have had diarrhoea / Yes as many as 26 children $(76.47 \%)$ and who have never experienced diarrhoea as many as eight children $(23.53 \%)$.

Table 10: Relationship between Feeding Patterns and Stunting

\begin{tabular}{|c|c|c|c|c|c|c|c|}
\hline \multirow{3}{*}{$\begin{array}{l}\text { Feeding } \\
\text { patterns }\end{array}$} & \multicolumn{4}{|c|}{ TB/Age nutritional status } & \multirow{2}{*}{\multicolumn{2}{|c|}{ Total }} & \multirow{3}{*}{$\begin{array}{c}P \text { - } \\
\text { Value }\end{array}$} \\
\hline & \multicolumn{2}{|c|}{ Very short } & \multicolumn{2}{|c|}{ Short } & & & \\
\hline & $\mathbf{n}$ & $\%$ & $\mathbf{n}$ & $\%$ & $\mathbf{N}$ & $\%$ & \\
\hline Good & 1 & 3,6 & 27 & 96,4 & 28 & 100 & \\
\hline Not good & 1 & 16,7 & 5 & 83,3 & 6 & 100 & 0,22 \\
\hline Total & 2 & 5,9 & 32 & 94,1 & 34 & 100 & \\
\hline
\end{tabular}

Based on table 10, it shows that the statistical test results obtained by the value of $p=0.22$ ( $p>0.05$ ), it can be concluded that there is no relationship between feeding patterns and the incidence of stunting in children under five in Sukahayu Village.

Table 11: Relationship between Tuberculosis History and Stunting

\begin{tabular}{|c|c|c|c|c|c|c|c|}
\hline \multirow{3}{*}{ TB History } & \multicolumn{4}{|c|}{ TB/Age nutritional status } & \multirow{2}{*}{\multicolumn{2}{|c|}{ Total }} & \multirow{3}{*}{$\begin{array}{c}P \text { - } \\
\text { Value }\end{array}$} \\
\hline & \multicolumn{2}{|c|}{ Very short } & \multicolumn{2}{|c|}{ Short } & & & \\
\hline & $\mathbf{n}$ & $\%$ & $\mathbf{n}$ & $\%$ & $\mathbf{N}$ & $\%$ & \\
\hline Yes & 0 & 0,0 & 5 & 100 & 5 & 100 & \\
\hline No & 2 & 6,9 & 27 & 93,1 & 29 & 100 & 0,55 \\
\hline Total & 2 & 5,9 & 32 & 94,1 & 34 & 100 & \\
\hline
\end{tabular}

Based on table 11, showing the statistical test results obtained by the value of $\mathrm{p}=0.55$ ( $\mathrm{p}>0.05$ ), it can be concluded that there is no relationship between TB history and the incidence of stunting in children under five in Sukahayu Village.. 
Table 12: Relationship History of Diarrhea and Stunting Incidence

\begin{tabular}{|c|c|c|c|c|c|c|c|}
\hline \multirow{3}{*}{$\begin{array}{c}\text { Diarrhea } \\
\text { History }\end{array}$} & \multicolumn{4}{|c|}{ Diarrhea/Age Nutritional status } & \multirow{2}{*}{\multicolumn{2}{|c|}{ Total }} & \multirow{3}{*}{$\begin{array}{c}P \text { - } \\
\text { Value }\end{array}$} \\
\hline & \multicolumn{2}{|c|}{ Very short } & \multicolumn{2}{|c|}{ Short } & & & \\
\hline & $\mathbf{n}$ & $\%$ & $\mathbf{n}$ & $\%$ & $\mathbf{N}$ & $\%$ & \\
\hline Yes & 1 & 3,8 & 25 & 96,2 & 26 & 100 & \\
\hline No & 1 & 12,5 & 7 & 87,5 & 8 & 100 & 0,37 \\
\hline Total & 2 & 5,9 & 32 & 94,1 & 34 & 100 & \\
\hline
\end{tabular}

Based on table 12, showing the statistical test results obtained by the value of $p=0.37$ ( $p>0.05$ ), it can be concluded that there is no relationship between the history of diarrhoea and the incidence of stunting in children under five in Sukahayu village.

After entering the data, the study results showed no relationship between the feeding patterns of stunting children with a p-value of 0.22 . It can be seen from the data that shows that $82.4 \%$ of the feeding pattern is good, and only $17.6 \%$ of the feeding pattern is not good. However, even though the percentage of a good dietary pattern was greater than that of a poor diet, 34 of the sampled children were still shorter than their age (stunting). It may be caused by other factors such as babies born with LBW, inadequate environmental sanitation, infectious diseases in children, anaemia in pregnant women and children. Different results were found in a study conducted by Widyaningsih et al that stated a significant relationship between eating patterns and the incidence of stunting, with a p-value of 0.05 (p-value $\leq$ 0.05).29,30 Different results were also found in research conducted by Nabuasa et al. That showed a relationship between diet and the incidence of stunting in children with an OR value or relationship strength of 3.16 .31

The feeding pattern of toddlers is the most important behaviour that can affect the state of nutrition. However, this is difficult to do, especially in varied diets rarely applied even though eating is generally two times a day. Therefore, even though the overall feeding pattern is good, stunting is still high because the food eaten is not varied. Other inhibiting factors that caused stunting but not related to feeding patterns, history of diarrhoea, and history of TB were not studied in this study. They are: cultural, family economy, low birth weight, malnutrition experienced by pregnant women and children under five, the mother's lack of health knowledge and nutrition before and during pregnancy, adherence to consuming Fe tablets, as well as after pregnant women, still limited health services including ANC services Ante Natal Care (health services for mothers during pregnancy) Post-Natal Care and quality early learning and lack of access to nutritious food so that there are still many children who are stunted even though the diet for toddlers is good.

Further research indicated no relationship between TB history and the incidence of stunting with a p-value of 0.55 ( $p>0.05$ ). It can be seen from the data that shows as many as $85.3 \%$ have never had TB history, and $14.7 \%$ of children under five have TB history. These results do not have a possible relationship because the number of children under five with a history of TB in Sukahayu Village is minimal. Nevertheless, these results are not in line with the research of Maryanto and Anugrah, which states that there is a significant relationship between TB and the incidence of stunting $(\mathrm{p}=0.010))^{32,33}$ In theory, TB and stunting are closely related because TB is an infectious disease that will affect the nutritional status of children. The first reaction due to infection is decreased appetite, so that toddlers will refuse to eat what is given. Refusal of food means reduced intake of nutrients in the body. TB with the incidence of stunting is a causal relationship. TB can worsen nutritional status and nutritional status, and malnutrition can make it easier for

\section{someone to catch infectious diseases.}

Further research also found no relationship between the history of diarrhoea and the incidence of stunting in children under five in Sukahayu village with a p-value of 0.37 ( $p>0.05$ ). It can be seen from the data, which shows as many as $76 \%$ children under five with diarrhoea are not stunted. Diarrhoea is closely related to malnutrition. Each episode of diarrhoea can result in a lack of ability to absorb food juices, so if the episodes are prolonged, it will impact the growth and health of the child. However, if given adequate nutrition, children who experience diarrhoea will reduce the risk of malnutrition and vice versa. The results of this study are in line with research conducted by Leo et al. Which stated that the incidence of diarrhoea was not a risk factor for the incidence of stunting with $p$-value 1 ( $p$ value> 0.05)..$^{34}$ Another possible direct cause of stunting is low levels of nutrient intake.

\section{CONCLUSION}

Based on the results of research and discussion, it can be concluded that: a) of 34 stunting respondents, 32 were short (94.1\%) and two very short (5.9\%); b) From 34 respondents, it was found that the age group of children under five was stunting at most at 25-36 months, namely 17 under five $(50 \%)$; c) Out of 34 respondents, the sex of children under five was equally stunted between males and females where 50\% each; d) In Sukahayu Village, from 34 respondents, it was found that 28 stunting toddlers had a good feeding pattern (82.4\%); e) In Sukahayu Village, from 34 respondents, it was found that five children under five with stunting had a history of TB (14.7\%); e) In Sukahayu Village, from 34 respondents, it was found that 26 children under five with stunting had a history of diarrhoea (76.5\%). Thus, there is no significant relationship between feeding patterns and a history of TB or diarrhoea with the incidence of stunting in stunting under five. Therefore, it is necessary to carry out further research by including various variables that are not included in this study seeing that there are still many factors associated with the incidence of stunting. In addition, it is hoped that the public and health workers, especially posyandu cadres, will receive education to find out earlier about the incidence of stunting in toddlers and provide a balanced nutrient intake to improve the health status of children.

\section{REFERENCES}

1. Mauluddin A, Novianti N. The Role of the Population, Family Planning and Family Development Program (KKBPK) in Reducing Stunting Prevalence. JCIC: Jurnal CIC Lembaga Riset Dan Konsultan Sosial. 2020 Mar 30; 2(1):19-28. https://doi.org/10.51486/jbo.v2i1.50

2. Benton D. The influence of dietary status on the cognitive performance of children. Molecular nutrition \& food research. 2010 Apr; 54(4):457-70.

https://doi.org/10.1002/mnfr.200900158 
3. Miranda JJ, Kinra S, Casas JP, Davey Smith G, Ebrahim S. Noncommunicable diseases in low-and middle-income countries: context, determinants and health policy. Tropical Medicine \& International Health. 2008 Oct; 13(10):1225-34. https://doi.org/10.1111/j.1365-3156.2008.02116.x

4. Schwarzenberg SJ, Georgieff MK. Advocacy for improving nutrition in the first 1000 days to support childhood development and adult health. Pediatrics. 2018 Feb 1; 141(2). https://doi.org/10.1542/peds.2017-3716

5. Willett W, Rockström J, Loken B, Springmann M, Lang T, Vermeulen S, Garnett T, Tilman D, DeClerck F, Wood A, Jonell M. Food in the Anthropocene: the EAT-Lancet Commission on healthy diets from sustainable food systems. The Lancet. 2019 Feb 2; 393(10170):447-92. https://doi.org/10.1016/S01406736(18)31788-4

6. Campisi SC, Cherian AM, Bhutta ZA. World perspective on the epidemiology of stunting between 1990 and 2015. Hormone research in paediatrics. 2017; 88(1):70-8. https://doi.org/10.1159/000462972

7. Candra A, Puruhita N, Susanto JC. Risk factors of stunting among 12 years old children in Semarang City. Media Medika Indonesiana. 2011; 45(3):206-12.

8. Teshome B, Kogi-Makau W, Getahun Z, Taye G. Magnitude and determinants of stunting in children underfive years of age in food surplus region of Ethiopia: the case of west gojam zone. Ethiopian Journal of Health Development. 2009; 23(2). https://doi.org/10.4314/ejhd.v23i2.53223

9. Bose K, Biswas S, Bisai S, Ganguli S, Khatun A, Mukhopadhyay A, Bhadra M. Stunting, underweight and wasting among Integrated Child Development Services (ICDS) scheme children aged 3-5 years of Chapra, Nadia District, West Bengal, India. Maternal \& child nutrition. 2007 Jul; 3(3):216-21. https://doi.org/10.1111/j.1740-8709.2007.00099.x

10. da Silva Ferreira H. Anthropometric assessment of children's nutritional status: a new approach based on an adaptation of Waterlow's classification. BMC pediatrics. 2020 Dec 1; 20(1):65. https://doi.org/10.1186/s12887-020-1940-6

11. Utami RA, Setiawan A, Fitriyani P. Identifying causal risk factors for stunting in children under five years of age in South Jakarta, Indonesia. Enfermeria clinica. 2019 Sep 1; 29:606-11. https://doi.org/10.1016/j.enfcli.2019.04.093

12. Kamal SM. Socio-economic determinants of severe and moderate stunting among under-five children of rural Bangladesh. Malaysian journal of nutrition. 2011 Mar 1; 17(1).

13. Langi, L.A., Clean and healthy living behavior with the stunting events in children in central Java, Indonesia. Systematic Reviews in Pharmacy, 2020; 11(12):127-133.

14. Olack B, Burke H, Cosmas L, Bamrah S, Dooling K, Feikin DR, Talley LE, Breiman RF. Nutritional status of under-five children living in an informal urban settlement in Nairobi, Kenya. Journal of health, population, and nutrition. 2011 Aug; 29(4):357. https://doi.org/10.3329/jhpn.v29i4.8451

15. Khan MZ, Law FC. Adverse effects of pesticides and related chemicals on enzyme and hormone systems of fish, amphibians and reptiles: a review. Proceedings of the Pakistan Academy of Sciences. 2005 Oct; 42(4):315-23.

16. Thairu L, Pelto G. Newborn care practices in Pemba Island (Tanzania) and their implications for newborn health and survival. Maternal \& child nutrition. 2008 Jul; 4(3):194-208. https://doi.org/10.1111/j.1740-8709.2008.00135.x

17. Kanotra S, D'Angelo D, Phares TM, Morrow B, Barfield WD, Lansky A. Challenges faced by new mothers in the early postpartum period: an analysis of comment data from the 2000 Pregnancy Risk Assessment Monitoring System (PRAMS) survey. Maternal and child health journal. 2007 Nov; 11(6):549-58. https://doi.org/10.1007/s10995-007-0206-3

18. Reidy KC, Deming DM, Briefel RR, Fox MK, Saavedra JM, Eldridge AL. Early development of dietary patterns: Transitions in the contribution of food groups to total energy-Feeding Infants and Toddlers Study, 2008. BMC Nutrition. 2017 Dec; 3(1):1-4. https://doi.org/10.1186/s40795-016-0124-0

19. Sun C, Xia W, Zhao Y, Li N, Zhao D, Wu L. Nutritional status survey of children with autism and typically developing children aged 4-6 years in Heilongjiang Province, China. Journal of nutritional science. 2013; 2. https://doi.org/10.1017/jns.2013.9

20. Butt G, Altaf F, Rani Z, Hussain I. Pulmonary tuberculosis in dermatological patients on high-dose, long-term steroid therapy. Journal of Pakistan Association of Dermatology. 2016 Nov 19; 25(2):119-31.

21. Batra S, Ayaz A, Murtaza A, Ahmad S, Hasan R, Pfau R. Childhood tuberculosis in household contacts of newly diagnosed TB patients. PLoS One. 2012 Jul 31; 7(7):e40880. https://doi.org/10.1371/journal.pone.0040880

22. Budihardjo SN, Suryawan IW, Sucipta AA. The relationship between nutritional status with length of stay in 1-5 years old children with diarrhea at Wangaya General Hospital Denpasar. IJBS. 2020; 14(2):113-7.

23. Murray JA, Rubio-Tapia A. Diarrhoea due to small bowel diseases Best practice \& research Clinical gastroenterology. 2012 Oct 1; 26(5):581-600. https://doi.org/10.1016/j.bpg.2012.11.013

24. Swartz TD, Duca FA, De Wouters T, Sakar Y, Covasa M. Upregulation of intestinal type 1 taste receptor 3 and sodium glucose luminal transporter-1 expression and increased sucrose intake in mice lacking gut microbiota. British Journal of Nutrition. 2012 Mar; 107(5):621-30. https://doi.org/10.1017/S0007114511003412

25. Kaukinen K, Peräaho M, Lindfors K, Partanen J, Woolley N, Pikkarainen P, KARVONEN AL, Laasanen T, Sievänen H, Mäki M, Collin P. Persistent small bowel mucosal villous atrophy without symptoms in coeliac disease. Alimentary pharmacology \& therapeutics. 2007 May; 25(10):1237-45. https://doi.org/10.1111/j.1365-2036.2007.03311.x

26. Camerlink I, Ellinger L, Bakker EJ, Lantinga EA. Homeopathy as replacement to antibiotics in the case of Escherichia coli diarrhoea in neonatal piglets. Homeopathy. 2010 Jan 1; 99(1):57-62. https://doi.org/10.1016/j.homp.2009.10.003

27. Reinstein E, Pimentel M, Pariani M, Nemec S, Sokol T, Rimoin DL. Visceroptosis of the bowel in the hypermobility type of EhlersDanlos syndrome: Presentation of a rare manifestation and review of the literature. European journal of medical genetics. 2012 Oct $1 ; 55(10): 548-51$. https://doi.org/10.1016/j.ejmg.2012.06.012

28. Tagaya E, Tamaoki J, Kondo M, Nagai A. Effect of a short course of clarithromycin therapy on sputum production in patients with chronic airway hypersecretion. Chest. 2002 Jul 1; 122(1):213-8. https://doi.org/10.1378/chest.122.1.213

29. Widyaningsih NN, Kusnandar K, Anantanyu S. Keragaman pangan, pola asuh makan dan kejadian stunting pada balita usia 24-59 bulan. Jurnal Gizi Indonesia (The Indonesian Journal of Nutrition). 2018; 7(1):22-9. https://doi.org/10.14710/jgi.7.1.22-29

30. Nadeak B, Iriani UE, Naibaho L, Sormin E, Juwita CP. Building Employees' Mental Health: The Correlation between Transactional Leadership and Training Program with Employees' Work Motivation at XWJ Factory. Indian Journal of Public Health Research \& Development. 2019; 10(6):1373-9. https://doi.org/10.5958/0976-5506.2019.01489.X

31. Nabuasa CD, Juffrie M, Huriyati E. History of parenting, diet, intake of nutrients associated with stunting in children 24-59 months in North Biboki, North Central Timor, East Nusa Tenggara. Jurnal Gizi dan Dietetik Indonesia (Indonesian Journal of Nutrition and Dietetics). 2016 Aug 25; 1(3):151-63. https://doi.org/10.21927/ijnd.2013.1(3).151-163

32. Maryanto S, Anugrah RM. Maryanto S, Anugrah RM. Hubungan antara penyakit tuberkulosis paru (Tb paru) dan BBLR dengan kejadian stunting pada siswa kelas 1 di SD Negeri Sambek Kecamatan Wonosobo. 2015.

33. Nadeak B, Naibaho L. The Description of medical students' interest and achievement on anatomy at faculty of medicine Universitas Kristen Indonesia. International Journal of Sciences: Basic and Applied Research (IJSBAR). 2018; 39(1):121-33.

34. Cahyati WH, Yuniastuti A. Disparity of Risk Factors Stunting on Toddlers in the Coast and the Mountain Areas of Sinjai, South Sulawesi. Public Health Perspective Journal. 2019 Oct 13; 4(3). 